\title{
ANALISIS EFEKTIVITAS KEPEMIMPINAN VIRTUAL KEPALA SEKOLAH DALAM MENINGKATKAN MOTIVASI KERJA GURU SEKOLAH MENENGAH ATAS
}

\author{
Eka Diana \\ Universitas Nurul Jadid, Paiton Probolinggo \\ ekadianaalwi8@gmail.com \\ Hiflatus Sunnah \\ Universitas Nurul Jadid, Paiton Probolinggo \\ hiflatussunnah7124@gmail.com \\ Sri Wahyuni Khoiriyah \\ Universitas Nurul Jadid, Paiton Probolinggo \\ sriwahyunikhoiriyah25@gmail.com
}

\begin{abstract}
This study aims to analyze the effectiveness of the principal's virtual leadership in relation to increasing teacher work motivation in the new normal era and the factors that influence it. This type of research uses a mix of qualitative and quantitative. The research location is in SMA Nurul Jadid Paiton Probolinggo. The research sample amounted to 20 people chosen randomly from the entire research population. Data collection techniques used interviews, documentation studies and questionnaires. The data analysis technique used descriptive statistics with the t-test of one


sample based on the sample used less than 30 . The results of the t-test obtained an average value of $82.7 \%$ which was in the effective category. The supporting factors for virtual leadership consist of communication skills and social networking skills. The inhibiting factors consist of geographical conditions and building trust.

Keywords: virtual leadership, teacher performance motivation, the new normal

\section{PENDAHULUAN}

Pendidikan merupakan usaha sadar serta terencana dalam meningkatkan kemampuan peserta didik, berakhlak mulia untuk menjadi insan yang bertakwa. Pendidikan terlaksana dalam lembaga pendidikan dimana lembaga pendidikan itu sendiri merupakan lembaga yang mempunyai kompleksitas dan keunikan tersendiri. Lembaga pendidikan dikatakan kompleks karena merupakan organisasi yang terdapat keterkaitan dimensi dalam mencapai komitmen pendidikan. Sedangkan dikatakan unik karena dalam lembaga pendidikan mempunyai karakteristik yang tidak terdapat dalam lembaga lainnya. Terkait dengan karakteristik tersebut adanya kegiatan proses belajar mengajar sebagai upaya untuk memanusiakan manusia ${ }^{1}$. Dengan kata lain adanya pendidikan yang diselenggarakan dalam lembaga pendidikanbertujuan untuk mngembangkan sumber daya sekolah menjadi insan kamil.

Lembaga pendidikan sebagai sebuah organisasi sosial bukan hanya membutuhkan seorang manajer dalam mengelola serta mengatur sumber daya sekolah yang berfokus pada pembiayaan dan administrasi saja, akan tetapi juga membutuhkan leader yang dapat mengedepankan visi lembaga dan komponen sumber daya yang berhubungan lembaga pendidikan tersebut. dengan demikian peran kepemimpinan pendidikan harus berjalan dengan optimal guna mencapai tujuan pendidikan dan kemajuan lembaga sekolah.

Kepala sekolah sebagai pemimpin sekaligus manajer agar menggerakkan serta mempengaruhi anggotanya untuk selalu mengembangkan dan meningkatkan motivasi kinerjanya agar mencapai tujuan pendidikan yang sudah ditentukan. Lebih lanjut dalam pandangan Mulyasa, kepala sekolah sebagai titik tumpu terciptanya perubahan maka peran kepala sekolah perlu disesuaikan dengan masyarakat yaitu: edukator, 'Syahrial Labaso', “KONSEP DASAR KEPEMIMPINAN DALAM PENDIDIKAN
ISLAM," Jurnal Al-Ghazali 1, no. 2 (2018): 82-102. 
manajer, administrator, supervisor, leader, inovator, serta motivator yang disingkat EMASLIM $^{2}$. Mengapa meningkatkan motivasi kinerja guru itu penting? Karena guru merupakan sumber daya yang bersinggungan langsung dengan peserta didik dalam pelaksanaan kegiatan proses pembelajaran. Selain itu guru juga merupakan motor penggerak dalam keberhasilan pendidikan guna mengembangkan dan meningkatkan kualitas peserta didik $^{3}$. Terdapatnya motivasi kinerja yang kuat pada diri guru maka akan mudah mencapai tujuan pendidikan. Begitu juga sebaliknya, jika dalam diri guru motivasi kinerjanya kurang maka otomatis akan mempengaruhi ketercapaian dalam tujuan pendidikan tersebut.

Peran seorang guru sangat dibutuhkan dalam proses pendidikan. Dimana kualitas pendidikan tercermin dari luaran atau output yang dihasilkan oleh sekolah tersebut. Guru yang mempunyai kemampuan yang baik akan mampu menjadi motivator yang baik bagi peserta didik ${ }^{4}$. Namun dalam kenyataannya masih banyak guru yang melaksanakan tugas belum sesuai dengan harapan masyarakat sekolah. Hal tersebut dapat dilihat dari: 1) Rendahnya pengetahuan dan pemahaman stategi pembelajaran; 2) Kurangnya kemampuan dalam pengelolaan kelas; 3) Rendahnya dalam melakukan PTK; 4) Kurangnya kedisiplinan; 5) Kurangnya komitmen dalam pekerjaan; serta 5) Kurangnya kemampuan manajemen waktu ${ }^{5}$. Melihat hal tersebut, sangat penting bagi pemimpin sekolah untuk meningkatkan dan mengembangkan motivasi kerja guru sehingga guru bisa bekerja dengan sesuai dengan komitmentnya untuk mencapai tujuan pendidikan.

Dalam masa sekarang dengan adanya pandemi Covid-19 telah melumpuhkan semua lini kehidupan termasuk pendidikan. Terdapatnya situasi pandemi ini mengharuskan pemerintah mengambil suatu kebijakan sebagai langkah memutus penyebaran corona yaitu dilakukan Pembatasan Sosial Berskala Besar (PSBB) yang menyebabkan semua lini kegiatan dihentikan dan bekerja dari rumah ${ }^{6}$. Dengan adanya kebijakan tersebut tentunya pelaku pendidikan tidak terkecuali kepala sekolah harus

\footnotetext{
2 Moh Rofiki and Wardatul Munawaroh, Pengantar Manajemen Pendidikan Islam Teori Dan Praktik Di Sekolah (Malang: CV Ampuh Multi Rejeki, 2021): 231-233.

${ }^{3}$ Moh Rofiki, "Urgensi Supervisi Akademik Dalam Pengembangan Profesionalisme Guru Di Era Industri 4.0," Indonesian Journal Pf Basic Education 2, no. 3 (2019): 502-14.

${ }^{4}$ Sulfi Purnamasari, "Efektivitas Kepemimpinan Kepala Sekolah Dalam Meningkatkan Kinerja Guru SMA Yaspen Tugu Ibu Depok," Eduka: Jrnal Pendidikan, Hukum Dan Bisnis 6, no. 1 (2021): 1-14.

${ }^{5}$ Risda Herawati Simarmata, "Upaya Peningkatan Motivasi Kerja Guru Sekolah Dasar," Jurnal Administrasi Pendidikan 4, no. 1 (2016): 654 - 831.

${ }^{6}$ Eka Diana and Moh Rofiki, "Analisis Metode Pembelajaran Efektif Di Era New Normal," Jurnal Review Pendidikan Dan Pengajaran 3 (2020): 336-42.
} 
berinovasi dalam melaksanakan kepemimpinan demi tercapainya tujuan pendidikan. Selain itu keadaan tersebut memberikan dampak terhadap kinerja guru dalam melakukan proses pembelajaran secara daring. Dengan melihat situasi tersebut dibutuhkan adanya langkah kongkrit yang dilakukan oleh kepala sekolah. Salah satu langkah tersebut adalah dengan melakukan kepemimpinan virtual, dimana kepala sekolah mengarahkan guru dari jarak jauh untuk melaksanakan pekerjaan demi tercapainya tujuan sekolah. Mereka memanfaatkan serta menggunakan teknologi dalam meningkatkan pekerjaan dan berkomunikasi dengan pengikut ${ }^{7}$.

Penelitian terdahulu telah banyak dilakukan terkait efektivitas kepemimpinan kepala sekolah ditinjau dari sudut pandang yang berbeda. Penelitian tentang efektivitas kepemimpinan kepala sekolah dalam meningkatkan kinerja guru yang dilakukan oleh Enas ${ }^{8}$. Dimana hasil penelitian tersebut menunjukkan kepemimpinan yang dilakukan efektif meningkatkan kinerja guru. Penelitian yang dilakukan Purnamasari tentang efektivitas kepemimpinan berdasarkan indikator perilaku yang berorientasi pada tugas dan hubungan dengan bawahan. Selanjutnya penelitian yang dilakukan oleh Zamroni et al. ${ }^{9}$ terkait E-leadership dalam meningkatkan kompetensi guru di era 4.0 dimana hasilnya menunjukkan bahwa implementasi e-leadership dalam meningkatkan kompetensi guru melalui perencanaan, pengorganisasian, pengarahan dan pendelegasian serta pengendalian.

Berdasarkan permasalahan dan beberapa hasil penelitian terdahulu, penelitian ini akan menganalisis efektivitas kepemimpinan virtual dalam meningkatkan motivasi kinerja guru. Adapun indikator yang dijadikan acuan terdiri dari kompetensi manajerial, kompetensi supervisi, kompetensi kepribadian, kompetensi kewirausahaan, dan kompetensi sosial ${ }^{10}$. Penelitian bertujuan untuk melihat efektivitas kepemimpinan virtual serta faktor-faktor yang mempengaruhi terhadap kepemimpinan virtual tersebut. Hasil penelitian dapat dijadikan acuan dalam melaksanakan kepemimpinan virtual bagi kepala sekolah lebih baik lagi

\footnotetext{
7 Ningky Sasanti Munir, "Kepemimpinan Di Era Digital (E-Leadership)," 2020, https://swa.co.id/swa/my-article/kepemimpinan-di-era-digital-e-leadership.

8 Enas, "Efektivitas Kepemimpinan Kepala Sekolah Dalam Meningkatkan Kinerja Guru," Journal of Management Review 2, no. 3 (2018): 252-60, https://jurnal.unigal.ac.id/index.php/managementreview/article/view/1808/1486.

${ }^{9}$ Zamroni et al., "E-Leadership in Education in Improving Teacher Competence in Industrial Revolution 4 . 0," Turkish Online Journal of Qualitative Inquiry (TOJQI) 12, no. 4 (2021): 1650-54.

${ }^{10}$ Menteri Pendidikan Nasional RI, "Permendiknas RI Nomor 13 Tahun 2007 Tentang Standar Kepala Sekolah/Madrasah” (Indonesia, 2007).
} 
serta mengantisipasi faktor yang menghambat pelaksanaan kepemimpinan tersebut.

\section{KAJIAN TEORI Kepemimpinan Virtual Kepala Sekolah}

Pengertian kepemimpinan menurut Saondi dalam Sagala ${ }^{11}$ adalah suatu proses bagaimana mengatur dan mencapai kinerja dalam rangka mencapai keputusan sebagaimana yang diinginkan. Dengan redaksi yang berbeda dengan makna sama Harsey dan Blanchard memberikan definisi kepemimpinan merupakan suatu proses mempengaruhi kegiatan individu atau kelompok dalam mencapai tujuan pada situasi tertentu ${ }^{12}$. Lebih lanjut pengertian kepemimpinan merupakan seni dan ilmu untuk mempengaruhi seseorang dan kelompok supaya bertindak sesuai dengan yang diharapkan. Kepemimpinan disebut seni dikarenakan setiap pemimpin dapat menerapkan teorinya disesuaikan dengan situasinya. Sedangkan kepemimpinan disebut ilmu dikarenakan dapat dipelajari secara ilmiah ${ }^{13}$.

Menurut M. R. Lee kepemimpinan virtual adalah suatu konsep yang menggunakan teknologi dalam melaksanakan kepemimpinan dalam suatu organisasi dan berbeda dengan gaya kepemimpinan konvensional 14. Dengan kata lain bahwa kepemimpinan virtual berbeda dengan kepemimpinan konvensional dari penggunaan media dan metode yang digunakan dalam melaksanakan kegiatan kepemimpinan tersebut. Istilah kepemimpinan virtual sendiri diperkenalkan oleh Avolio, Kahai, dan Dodge, dimana menurutnya kepemimpinan virtual merupakan kepemimpinan yang dilakukan melalui internet dan berfungsi sebagai komunikasi, pengumpulan serta penyebaran suatu informasi ${ }^{15}$. Lebih rinci lagi Hinds, Kiesler \& Kiesler memberikan pengertian bahwa kepemimpinan virtual mempunyai makna bahwa seorang pemimpin dalam melaksanakan tugas dan tanggungjawabnya dalam pengambilan

\footnotetext{
11 Syaiful Sagala, "Manajemen Dan Kepemimpinan Pendidikan Pondok Pesantren," Jurnal Tarbiyah 22, no. 2 (2015): 205-25.

12 Wahyudin Nur Nasution, "Kepemimpinan Pendidikan Di Sekolah," Jurnal Tarbiyah 22, no. 1 (2015): 66-86.

13 Sagala, "Manajemen Dan Kepemimpinan Pendidikan Pondok Pesantren."

14 Iwan Hermawan, Sri Eka Sadriatwati, and Nur Indah, "Virtual Leadership, Energizing Team Learning, Affective Commitment," Prosiding Seminar Hasil Penelitian Dan Pengabdian Masyarakat Polines 3 (2020): 307-25.

${ }_{15}$ M.Mas'ud Leman, "Pengaruh Gaya Kepemimpinan Virtual Terhadap Penguasaan Manajemen Dan Kinerja Kepala SD Di Tanah Grogot Kalimantan Timur," Jurnal Cendikia 14, no. 2 (2020): 196-211, https://doi.org/10.30957/Cendekia.v14i2.642.Sebagai.
} 
keputusan serta pemecahan masalah menggunakan media elektronik ${ }^{16}$. Berdasarkan beberapa penjelasan di atas maka dapat diberikan pengertian bahwasanya kepemimpinan virtual merupakan suatu proses untuk mempengaruhi orang lain melakukan tindakan tertentu dengan menggunakan teknologi dalam pelaksanaannya untuk mencapai tujuan sekolah. Esensi kepemimpinan virtual menurut Wahab terdiri dari unsurunsur utama, yaitu: unsur leader, followers, interaksi, tujuan serta perilaku ${ }^{17}$. Unsur pemimpin merupakan unsur utama dimana pemimpin harus dapat mempengaruhi anggotanya agar dapat melaksanakan kegiatan yang diberikan oleh pemimpin. Orang yang dipimpin merupakan anggota yang diberikan tugas untuk melaksanakan apa yang sudah diberikan oleh pemimpin. Interaksi merupakan komunikasi antara pimpinan dalam mempengaruhi bawahannya. Tujuan merupakan target yang ingin dicapai oleh pemimpin dalam mempengaruhi bawahannya. Serta perilaku ialah hasil yang telah dicapai oleh pemimpin dalam mempengaruhi bawahannya.

Pemimpin virtual dalam hal ini kepala sekolah harus mengarahkan bawahannya untuk melaksanakan pekerjaan dari jarak jauh dalam mencapai suatu tujuan. Kepala sekolah menggunakan teknologi baru yang terkoneksi dengan internet dalam melakukan tugas dan fungsinya misalnya aplikasi Zoom, Google meet, dan lain sebagainya. Oleh karena itu diperlukan kesiapan sumber daya manusia dalam pemanfaatan teknologi dan informasi yang tepat guna ${ }^{18}$. Terdapat berapa tantangan yang akan dihadapi oleh pemimpin virtual dalam melaksanakan kepepimpinan virtual yaitu minimnya interaksi fisik dengan anggota serta kurangnya kepercayaan dari anggota tim.

Oleh sebab itu menurut John dalam Hermawan et al. ${ }^{19}$ seorang pemimpin virtual harus memiliki beberapa kompetensi dalam melaksanakan kepemimpinan virtual. Pertama, keahlian berkomunikasi (communication skills). Seorang pemimpin virtual dituntut untuk berkomunikasi dengan bawahannya secara efektif melalui media teknologi yang tersedia. Dengan komunikasi tersebut pemimpin harus mampu menjalankan tugasnya, memberikan arahan kepada bawahannya, dan menetapkan tujuan sehingga bawahannya dengan mudah memahaminya. Kedua, atribut pribadi (personal attributes) dan membangun

\footnotetext{
${ }^{16}$ Hermawan, Sadriatwati, and Indah, "Virtual Leadership, Energizing Team Learning, Affective Commitment,."

${ }^{17}$ Nasution, "Kepemimpinan Pendidikan Di Sekolah."

${ }^{18}$ Zamroni et al., "E-Leadership in Education in Improving Teacher Competence in Industrial Revolution 4 . 0."

${ }^{19}$ Hermawan, Sadriatwati, and Indah, "Virtual Leadership, Energizing Team Learning, Affective Commitment,."
} 
kepercayaan (trust building). Atribut pribadi sangat penting kedudukannya. Seorang pemimpin sangat memerlukan adanya atribut yang melekat dalam dirinya seperti keterbukaan dalam berpikir, kejujuran, kepekaan, dan lain-lain sehingga dapat membangun kepercayaan anggota. Selain itu juga diperlukan keahlian dalam beradaptasi secara cepat dengan lingkungan baru ${ }^{20}$. Hal ini juga penting mengingat dengsn adanya teknologi informasi dan komunikasi (TIK) yang berkembang sangat pesat akan membutuhkan kemampuan beradaptasi secara cepat dengan lingkungan sehingga dapat melaksanakan tugas dan fungsinya.

Dalam melihat kepemimpinan virtual kepala sekaolah, indikator atau acuannya dalam hal ini sebagaimana tertuang dalam Permediknas perihal Standar Kepala Sekolah/Madrasah ${ }^{21}$ adalah kompetensi kepribadian, manajerial, kewirausahaan, supervisi, serta sosial. Kompetensi kepribadian terdiri dari: 1) berakhlak mulia, meningkatkan budaya dan tradisi akhlak mulia, serta menjadi teladan bagi komunitas di sekolah; 2) mempunyai integritas kepribadian sebagai seorang pemimpin; 3) mempunyai kemauan yang kuat untuk mengembangakan diri sebagai pemimpin; 4) memiliki sikap terbuka dalam melaksanakan tupoksi sebagai kepala sekolah; 5) mengenalikan diri dalam menghadapi problem pekerjaan sebagai kepala sekolah; serta 6) mempunyai bakat serta minat jabatan sebagai kepala sekolah. Kompetensi manajerial meliputi: 1) membuat perencanaan sekolah dalam berbagai tingkatan perencanaan; 2) meningkatkan organisasi sekolah sesuai dengan kebutuhan; 3) memimpin sekolah dalam pendayagunaan sumber daya sekolah dengan optimal; 4) mengelola pengembangan dan perubahan sekolah menuju pembelajaran efektif; 5) menciptakan budaya serta iklim sekolah yang kondusif dan inovatif bagi pemebelajaran siswa; 6) mengelola guru serta staf dengan optimal; 7) mengelola sarpras dengan optimal; 8) mengelola humas dalam mencari dukungan ide, sumber belajar, serta pembiayaan sekolah; 9) mengelola siswa kaitannya dengan penerimaan siswa baru, penempatan serta pengembangan kapasitas siswa; 10) mengelola kurikulum serta pembelajaran sesuai tujuan pendidikan; 11) mengelola keuangan sekolah dengan akuntabel, trasparan, serta efisien; 12) mengelola ketatausahan sekolah guna mencapai tujuan sekolah; 13) mengelola unit layanan khusus sekolah guna mendukung pembelajaran serta kegiatan siswa; 14) mengelola sistem informasi sekolah guna mendukung penyusunan progran dan pengambilan keputusan; 15) memanfaatkan kemajuan

20 Marketeers, "Virtual Leadership: Gaya Baru Kepemimpinan Efektif," 2012, https://www.marketeers.com/virtual-leadership-gaya-baru-kepemimpinan-efektif/.

21 "Permendiknas RI Nomor 13 Tahun 2007 Tentang Standar Kepala Sekolah/Madrasah." 
teknologi informasi dalam pembelajaran serta manajemen sekolah; dan 16) melakukan monev serta pelaporan pelaksanaan program sekolah. Kompetensi kewirausahaan meliputi: 1) menciptakan inovasi yang bermanfaat bagi sekolah; 2) berkerja keras dalam mencapai keberhasilan sekolah; 3) mempunyai motivasi yang kuat untuk melaksanakan tupoksi sebagai pemimpin; 4) pantang menyerah serta selalu mencari solusi terbaik; 5) mempunyai naluri kewirausahaan dalam mengelola kegiatan sekolah. Kompetensi supervisi terdiri dari: 1) merencanakan supervisi akademik dalam peningkatan profesionalime guru; 2) melakukan supervisi akademik kepada guru melalui pendekatan dan teknik yang tepat; 3) menindaklanjuti hasil supervisi akademik guru dalam rangka peningkatan profesionalisme guru. Kompetensi sosial meliputi: 1) bekerja sama dengan pihak lain untuk kepentingan sekolah; 2) ikut serta dalam kegiatan sosial kemasyarakatan; 3) mempunyai kepekaan sosial terhadap orang atau kelompok lain.

\section{Motivasi Kerja Guru}

Motivasi ialah dorongan seseorang untuk melakukan sesuatu, baik dorongan dalam diri sendiri maupun dari luar. Motivasi dalam pandangan Hasibuan ialah pemberian daya penggerak yang membuat seseorang bergairah agar mau bekerja efektif, bekerja sama, serta terintegrasi dengan segala usahanya dalam memperoleh kepuasan ${ }^{22}$. Menurut Sukmadinata motivasi merupakan suatu kekuatan (power) yang terdapat pada diri seseorang yang mendorong serta menggerakkan untuk bertindak dalam mencapai tujuan ${ }^{23}$. Dengan redaksi berbeda dan makna yang sama dikemukakan oleh Wahjusumidjo dalam Listiani ${ }^{24}$ motivasi merupakan semangat kerja yang terdapat dalam diri sendiri untuk berperilaku agar mencapai tujuan yang ditentukan.

Sedangkan menurut Irwanto sebagaimana dikutip Jamali \& Prasojo ${ }^{25}$ motivasi adalah penggerak dan penentu sesuatu. Dimana terdapatnya kebutuhan seseorang telah menimbulkan ketegangan yang mendorong

\footnotetext{
22 Dedy Kusumah Wijaya, "Pentingnya Komunikasi Organisasi, Motivasi Kerja Dan Kompensasi Untuk Meningkatkan Kinerja Guru," Jurnal MIX VI, no. 2 (2015): 275-90. ${ }^{23}$ Mohammad Zulkifli, Arif Darmawan, and Edy Sutrisno, "Motivasi Kerja, Sertifikasi, Kesejahteraan Dan Kinerja Guru," Persona:Jurnal Psikologi Indonesia 3, no. 2 (2014): 14855, https://doi.org/10.30996/persona.v3i02.379.

${ }^{24}$ Rita Lisnawati, "Fungsi Manajemen Kepala Sekolah, Motivasi, Dan Kinerja Guru," Jurnal Pendidikan (Teori Dan Praktik) 2, no. 2 (2018): 143, https://doi.org/10.26740/jp.v2n2.p143-149.

25 Arif Jamali and Lantip Diat Prasojo, "Pengaruh Kompetensi Manajerial Kepala Sekolah, Lingkungan, Motivasi Guru Terhadap Prestasi Siswa SMA Muhammadiyah Kota Yogyakarta,” Jurnal Akuntabilitas Manajemen 1, no. 1 (2013): 8-21.
} 
untuk memenuhi kebutuhan tersebut. Tensi atau ketegangan akan melemah jika kebutuhan telah terpenuhi, begitu juga ketegangan akan muncul kembali ketika terdapat kebutuhan baru dan begitu seterusnya sehingga hal ini disebut dengan daur motivasi. Lebih jelasnya lihat gambar berikut:

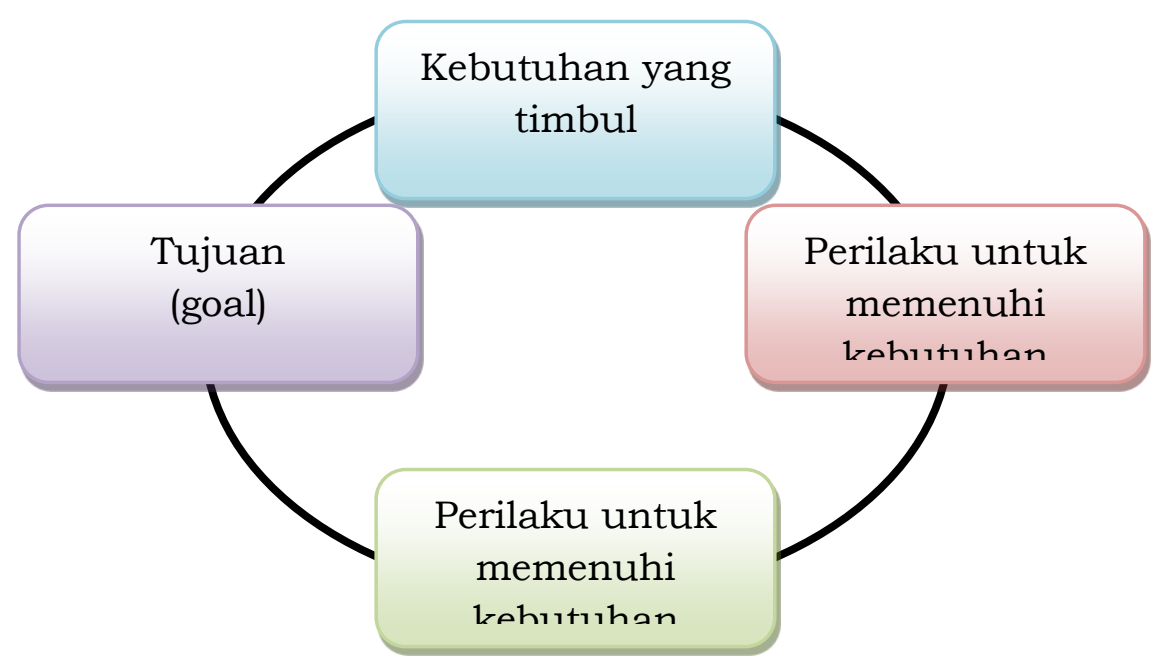

Gambar 1. Daur Motivasi

Berdasarkan berbagai penjelasan di atas, maka dapat diberikan kesimpulan bahwa motivasi merupakan suatu kekuatan (power) yang berasal dari diri individu untuk mendorong melakukan sesuatu dalam rangka mencapai tujuan yang ditentukan.

Lebih lanjut, kinerja menurut Arikunto adalah alih bahasa dari terma penampilan yang berarti suatu yang dapat diobservasi orang lain ${ }^{26}$. Menurut pendapat Rivai kinerja merupakan tindakan nyata yang ditampakkan oleh seseorang atas prestasi kerja yang dihasilkan sesuai dengan peranannya. Dengan kata lain kinerja ialah hasil kerja yang telah diperoleh oleh seseorang serta kelompok dalam sebuah organisasi. Dalam kaitannya dengan kinerja guru Rahmawati memberikan pengertian kinerja guru merupakan kompetensi yang diperlihatkan oleh guru dalam melakukan tugas dalam pekerjaannya, dimana kinerja tersebut dikategorikan memuaskan apabila hasil yang diperoleh sesuai standar

\footnotetext{
26 Zulkifli, Darmawan, and Sutrisno, "Motivasi Kerja, Sertifikasi, Kesejahteraan Dan Kinerja Guru."
} 
yang telah ditentukan ${ }^{27}$. Terkait standar kinerja guru, Sahertian dalam Wijaya ${ }^{28}$ memberikan penjelasan bahwa standar kinerja guru berkaitan dengan kualitas seorang guru dalam melakukan tugasnya, yaitu 1) bekerja bersama siswa secara individual; 2) merencanakan serta mempersiapkan pembalajaran yang akan dilaksanakan; 3) pendayagunaan dan pemanfaatan media pembelajaran; 4) mengikutsertakan siswa dalam berbagai pengalaman belajar, serta 5) kepemimpinan aktif oleh guru.

Adapun yang dimaksud dengan motivasi kinerja guru adalah faktor-faktor yang mendorong guru lebih semangat dalam melaksanakan tugasnya sehingga mendapatkan prestasi yang baik. faktor tersebut adalah faktor dari dalam (intrinsik) dan faktor dari luar (ekstrinsik). Faktor instrinsik merupakan faktor yang berasal dalam diri guru. Dimana indikator faktor ini yaitu keinginan untuk maju, keinginan akan prestasi, mempunyai kehidupan pribadi dll. Faktor ekstrinsik merupakan faktor yang berasal dari luar. Dimana indikator ekstrinsik yaitu pekerjaan, tempat pekerjaan, status pekerjaan, penghasilan yang layak, dll ${ }^{29}$. Lebih lanjut menurut Hackman terdapat empat hal penting yang dapat meningkatkan motivasi kinerja guru yaitu: 1) aspek inti dari suatu pekerjaan; 2) situasi kritis pekerjaaan secara psikologis; 3) hasil kerja serta kepribadian, dan 4) pertumbuhan kebutuhan individu ${ }^{30}$.

\section{METODE PENELITIAN}

Jenis penelitian yang digunakan adalah gabungan (mix) kualitatif dan kuantitatif, dimana penelitian bertujuan untuk menganalisis efektifitas kepemimpinan virtual kepala sekolah kaitannya dengan meningkatkan motivasi kinerja guru. Lokasi atau tempat penelitian di SMA Nurul Jadid Paiton Probolinggo. Sampel penelitian berjumlah 20 orang yang diambil secara acak (random) dari jumlah keseluruhan populasi. Populasi penelitian adalah seluruh guru SMA Nurul Jadid Paiton Probolinggo.

Teknik pengumpulan data menggunakan interview, studi dokumentasi serta sebaran angket terkait efektivitas kepemimpinan

\footnotetext{
27 Yesmira Syamra, "Pengaruh Kompensasi Finansial Dan Motivasi Kerja Guru Terhadap Kinerja Guru Smk Negeri Pariwisata Di Kota Padang," Economica 4, no. 2 (2016): 266-76, https://doi.org/10.22202/economica.v4i2.628.

${ }^{28}$ Wijaya, "Pentingnya Komunikasi Organisasi, Motivasi Kerja Dan Kompensasi Untuk Meningkatkan Kinerja Guru."

29 Tasrim and Elihami, "MAHAGURU: Jurnal Pendidikan Guru Sekolah Dasar MOTIVASI KERJA PENDIDIK DALAM MENINGKATKAN MANAJEMEN LEMBAGA PENDIDIKAN DASAR,” 2019, 42-47.

30 Tasrim and Elihami.
} 
virtual kepala sekolah. Interview dilakuskan kepada kepala sekolah, wakil kepala sekolah dan guru. Interview yang digunakan adalah interview semi terstruktur.

Teknik analisis menggunakan statistik deskriptif. Dimana untuk analisis terkait efektivitas kepemimpinan virtual dalam meningkatkan motivasi kinerja guru menggunakan analisis persentase diskriptif kuantitatif dengan mendiskripsikan persentase yang diperoleh kemudian penafsiran data tersebut dengan statistik guna mendapatkan kesimpulan mengenai efektivitas kepemimpinan virtual dalam meningkatkan motivasi kinerja guru. Untuk mendapatkan nilai rata-rata dari responden dilakukan dengan uji t satu sampel. Penggunaan uji t satu sampel didasarkan atas jumlah sampel yang digunakan kurang dari 30. Selanjutnya menentukan kriteria efektifitas kepemimpinan virtual kepala sekolah ${ }^{31}$.

Tabel 1. Klasifikasi/Kategori

Kepemimpinan Virtual Kepala Sekolah

\begin{tabular}{|l|l|l|}
\hline No & $\begin{array}{l}\text { Interval Persentase } \\
\text { Nilai Rata-rata (\%) }\end{array}$ & Klasifikasi/Kategori \\
\hline 1 & $84-100$ & Sangat Efektif \\
\hline 2 & $67-83$ & Efektif \\
\hline 3 & $50-66$ & Cukup Efektif \\
\hline 4 & $49-65$ & Kurang Efektif \\
\hline 5 & $<49$ & Tidak Efektif \\
\hline
\end{tabular}

HASIL DAN PEMBAHASAN

Efektivitas kepemimpinan virtual dilihat dari kompetensi manajerial dalam meningkatkan motivasi kinerja guru

Tabel 2. Kompetensi Manajerial Kepala Sekolah

\begin{tabular}{|c|l|c|c|}
\hline No & \multicolumn{1}{|c|}{ Indikator } & Persentase & Kategori \\
\hline 1 & $\begin{array}{l}\text { Melakukan perencanaan dalam berbagai } \\
\text { tingkatan. }\end{array}$ & 84.2 & $\begin{array}{l}\text { Sangat } \\
\text { efektif }\end{array}$ \\
\hline 2 & $\begin{array}{l}\text { Menekankan pengembangan sekolah sesuai } \\
\text { kebutuhan. }\end{array}$ & 80.1 & Efektif \\
\hline 3 & $\begin{array}{l}\text { Menekankan pelaksanaan kepemimpinan } \\
\text { dalam pendayagunaan SDM secara optimal. }\end{array}$ & 85.5 & $\begin{array}{l}\text { Sangat } \\
\text { efektif }\end{array}$ \\
\hline 4 & $\begin{array}{l}\text { Menekankan perubahan menuju } \\
\text { pembelajaran efektif. }\end{array}$ & 84 & $\begin{array}{l}\text { Sangat } \\
\text { efektif }\end{array}$ \\
\hline 5 & Menekankan terciptanya budaya dan & 82 & Efektif \\
\hline
\end{tabular}

31 Purnamasari, "Efektivitas Kepemimpinan Kepala Sekolah Dalam Meningkatkan Kinerja Guru SMA Yaspen Tugu Ibu Depok.” 


\begin{tabular}{|c|c|c|c|}
\hline & keadaan yang kondusif. & & \\
\hline 6 & $\begin{array}{l}\text { Menekankan hubungan yang harmonis } \\
\text { dengan masyarakat. }\end{array}$ & 85.1 & $\begin{array}{l}\text { Sangat } \\
\text { efektif }\end{array}$ \\
\hline 7 & $\begin{array}{l}\text { Menekankan pengembangan dan } \\
\text { pembelajaran kurikulum sesuai tujuan } \\
\text { pendidikan. }\end{array}$ & 82.3 & Efektif \\
\hline 8 & $\begin{array}{l}\text { Melaksanaan pengelolaan keuangan sekolah } \\
\text { dengan akuntabel,transparan serta efiesien. }\end{array}$ & 80.4 & Efektif \\
\hline 9 & $\begin{array}{l}\text { Menekankan pengelolaan sistem informasi } \\
\text { sekolah dalam pengambilan keputusan. }\end{array}$ & 86 & $\begin{array}{l}\text { Sangat } \\
\text { efektif }\end{array}$ \\
\hline 10 & $\begin{array}{l}\text { Menekankan pemanfaatan kemajuan } \\
\text { teknologi informasi dalam manajemen } \\
\text { sekolah. }\end{array}$ & 84.2 & $\begin{array}{l}\text { Sangat } \\
\text { efektif }\end{array}$ \\
\hline 11 & $\begin{array}{l}\text { Menekankan pengelolaan sarpras sekolah } \\
\text { secara optimal. }\end{array}$ & 79 & Efektif \\
\hline 12 & $\begin{array}{l}\text { Menekankan pengelolaan sumber daya guru } \\
\text { dan staff dengan optimal. }\end{array}$ & 84 & $\begin{array}{l}\text { Sangat } \\
\text { efektif }\end{array}$ \\
\hline 13 & $\begin{array}{l}\text { Menekankan pengelolaan layanan unit } \\
\text { khusus. }\end{array}$ & 68.8 & Efektif \\
\hline 14 & $\begin{array}{l}\text { Menekankan pengelolaan ketatausahaan } \\
\text { untuk mencapai tujuan sekolah. }\end{array}$ & 72.4 & Efektif \\
\hline 15 & $\begin{array}{l}\text { Menekankan pengelolaan peserta didik } \\
\text { dengan optimal. }\end{array}$ & 82.5 & Efektif \\
\hline 16 & $\begin{array}{l}\text { Menekankan pelaksanaan dalam } \\
\text { menonitoring, evaluasi serta pelaporan } \\
\text { kegiatan sesuai dengan prosedur. }\end{array}$ & 83 & Efektif \\
\hline & Rata-rata & 81.47 & Efektif \\
\hline
\end{tabular}

Berdasarkan tabel di atas, efektivitas kepemimpinan virtual kepala sekolah ditinjau dari kompetensi manajerial berada pada persentase $81,47 \%$ dengan kategori efektif. Dari 16 indikator dalam penilaian tersebut masih terdapat nilai rata-rata yang menunjukkan masih belum optimalnya kepemimpinan virtual kepala sekolah yaitu indikator pengelolaan sarpras sekolah dan pengelolaan tatausaha.

\section{Efektivitas kepemimpinan virtual dilihat dari kompetensi supervisi dalam meningkatkan motivasi kinerja guru}

Tabel 3. Kompetensi Supervisi Kepala Sekolah

\begin{tabular}{|c|l|c|c|}
\hline No & \multicolumn{1}{|c|}{ Indikator } & Persentase & Kategori \\
\hline 1 & Menekankan koordinasi usaha sekolah. & 85 & $\begin{array}{c}\text { Sangat } \\
\text { efektif }\end{array}$ \\
\hline 2 & Menekankan pengembangan pengalaman & 86.3 & Sangat \\
\hline
\end{tabular}




\begin{tabular}{|c|l|c|c|}
\hline & guru-guru. & & efektif \\
\hline 3 & Menekankan stimulasi dalam usaha kreatif. & 78.4 & Efektif \\
\hline 4 & $\begin{array}{l}\text { Menekankan penilaian dan pemberian } \\
\text { fasilitas. }\end{array}$ & 76 & Efektif \\
\hline 5 & Melakukan analisis dalam KBM & 80.3 & Efektif \\
\hline 6 & $\begin{array}{l}\text { Menekankan pemberian pengetahuan dan } \\
\text { keterampilan. }\end{array}$ & 78 & Efektif \\
\hline 7 & $\begin{array}{l}\text { Menekankan peningkatan kemampuan } \\
\text { guru dalam KBM. }\end{array}$ & 84.7 & $\begin{array}{l}\text { Sangat } \\
\text { efektif }\end{array}$ \\
\hline & Rata-rata & 81.24 & Efektif \\
\hline
\end{tabular}

Dari tabel di atas, nilai rata-rata kepemimpinan virtual kepala sekolah dilihat dari kompetensi supervisi berada dalam kategori efektif. Hal ini didasarkan dari nilai rata-rata dengan persentase $81,24 \%$ dari 7 indikator. Kepemimpinan virtual sepenuhnya belum optimal dilihat dari indikator kompetensi supervisi yaitu stimulasi usaha kreatif, penilaian dan pemberian fasilitas serta pemberian pengetahuan dan keterampilan.

\section{Efektivitas kepemimpinan virtual dilihat dari kompetensi kewirausahaan dalam meningkatkan motivasi kinerja guru}

Tabel 4. Kompetensi Kewirausahaan Kepala Sekolah

\begin{tabular}{|c|l|c|c|}
\hline No & \multicolumn{1}{|c|}{ Indikator } & Persentase & Kategori \\
\hline 1 & $\begin{array}{l}\text { Menciptakan inovasi bagi } \\
\text { pengembangan sekolah. }\end{array}$ & 83.2 & Efektif \\
\hline 2 & $\begin{array}{l}\text { Menekankan kerja keras dalam } \\
\text { mencapai tujuan. }\end{array}$ & 82.8 & Efektif \\
\hline 3 & $\begin{array}{l}\text { Menekankan motivasi dalam } \\
\text { melaksanakan tugas. }\end{array}$ & 85.4 & Sangat efektif \\
\hline 4 & $\begin{array}{l}\text { Menekankan poblem solving dan } \\
\text { pantang menyerah. }\end{array}$ & 80.2 & Efektif \\
\hline 5 & Mempunyai naluri kewirausahaan. & 81.7 & Efektif \\
\hline & Rata-rata & 82.66 & Efektif \\
\hline
\end{tabular}

Tabel di atas menunjukkan dari 5 indikator kompetensi kewirausahaan, kepemimpinan virtual kelapa sekolah berada dalam kategori efektif dengan nilai mean 82,66\%. Dalam kepemimpinan virtual ditinjau dari kompetensi kewirausahan sepenuhnya optimal. 
Efektivitas kepemimpinan virtual dilihat dari kompetensi kepribadian dalam meningkatkan motivasi kinerja guru

Tabel 5. Kompetensi Kepribadian Kepala Sekolah

\begin{tabular}{|c|l|c|c|}
\hline No & \multicolumn{1}{|c|}{ Indikator } & Persentase & Kategori \\
\hline 1 & $\begin{array}{l}\text { Menekankan pengembangan budaya, } \\
\text { berakhlak mulia dan menjadi teladan. }\end{array}$ & 85 & $\begin{array}{c}\text { Sangat } \\
\text { efektif }\end{array}$ \\
\hline 2 & $\begin{array}{l}\text { Menekankan integritas sebagai } \\
\text { pemimpin. }\end{array}$ & 84.8 & $\begin{array}{c}\text { Sangat } \\
\text { efektif }\end{array}$ \\
\hline 3 & Menekankan pengembangan diri. & 83.3 & Efektif \\
\hline 4 & $\begin{array}{l}\text { Menekankan sikap terbuka dalam } \\
\text { melaksanakan tugas. }\end{array}$ & 84.2 & $\begin{array}{c}\text { Sangat } \\
\text { efektif }\end{array}$ \\
\hline 5 & Melakukan analisis dalam KBM & 83.8 & Efektif \\
\hline 6 & $\begin{array}{l}\text { Menekankan pengendalian diri dalam } \\
\text { menghadapi problem. }\end{array}$ & 80 & Efektif \\
\hline 7 & $\begin{array}{l}\text { Mempunyai bakat dan minat dalam } \\
\text { memimpin. }\end{array}$ & 84.8 & $\begin{array}{c}\text { Sangat } \\
\text { efektif }\end{array}$ \\
\hline & Rata-rata & 83.7 & Efektif \\
\hline
\end{tabular}

Berdasarkan tabel di atas, menunjukkan bahwa kepemimpinan virtual kepala sekolah berjalan optimal. Hal tersebut ditunjukkan dengan 7 indikator kompetensi kepribadian yang berada dalam kategori sangat efektif dengan nilai mean $84,8 \%$.

Efektivitas kepemimpinan virtual dilihat dari kompetensi sosial dalam meningkatkan motivasi kinerja guru

Tabel 6. Kompetensi Sosial Kepala Sekolah

\begin{tabular}{|c|l|c|c|}
\hline No & \multicolumn{1}{|c|}{ Indikator } & Persentase & Kategori \\
\hline 1 & $\begin{array}{l}\text { Menekankan kerjasama dengan } \\
\text { masyarakat dan komunitas. }\end{array}$ & 85 & $\begin{array}{l}\text { Sangat } \\
\text { efektif }\end{array}$ \\
\hline 2 & $\begin{array}{l}\text { Menekankan ikut serta dalam kegiatan } \\
\text { sosial. }\end{array}$ & 84.1 & $\begin{array}{l}\text { Sangat } \\
\text { efektif }\end{array}$ \\
\hline 3 & $\begin{array}{l}\text { Menekankan kepekaan sosial terhadap } \\
\text { orang kain. }\end{array}$ & 83.4 & Efektif \\
\hline & Rata-rata & 84.17 & $\begin{array}{l}\text { Sangat } \\
\text { efektif }\end{array}$ \\
\hline
\end{tabular}

Kepemimpinan virtual kepala sekolah ditinjau dari kompetensi sosial dalam kategori sangat efektif. Hal ini terlihat dari tabel di atas yang memperoleh nilai mean $84,17 \%$ dengan 3 indikator kompetensi sosial. 
Kepemimpinan virtual kepala sekolah berjalan optimal mengingat dari 3 indikator tersebut semuanya berada di atas $80 \%$.

Tabel 7. Hasil uji t satu sampel-SPSS

\begin{tabular}{|l|c|c|c|c|}
\hline \multicolumn{5}{|c|}{ One-Sample Statistics } \\
\hline & $\mathrm{N}$ & Mean & $\begin{array}{c}\text { Std. } \\
\text { Deviation }\end{array}$ & $\begin{array}{c}\text { Std. } \\
\text { Error Mean }\end{array}$ \\
\hline $\begin{array}{l}\text { Efektivitas Kepemimpinan } \\
\text { Virtual }\end{array}$ & 20 & 82.7325 & 5.80976 & 1.29910 \\
\hline
\end{tabular}

Berdasarkan hasil uji t satu sampel di atas, menunjukkan bahwa nilai mean efektivitas kepemimpinan virtual kepala sekolah dalam meningkatkan motivasi kinerja guru yaitu $82,7 \%$ berada dalam interval nilai rata-rata 64-83\% dengan kategori efektif.

\section{Faktor-faktor yang mempengaruhi Efektivitas kepemimpinan virtual dalam meningkatkan motivasi kinerja guru}

Efektivitas kepemimpinan virtual kepala sekolah dalam meningkatkan motivasi kinerja guru dipengaruhi oleh faktor pendukung dan faktor penghambat di dalam pelaksanaannya. Faktor pendukung merupakan faktor yang membantu dalam pelaksanaan kepemimpinan virtual kepala sekolah. Berdasarkan hasil observasi dan interview dengan beberapa koresponden diperoleh bahwa faktor pendukung tersebut adalah keahlian berkomunikasi (communication skill) dan kemampuan jaringan sosial (sosial networking skill). Sedangkan faktor penghambat merupakan faktor yang menyebabkan tidak optimalnya pelaksanaan kepemimpinan virtual kepala sekolah. Berdasarkan hasil observasi dan interview dengan beberapa koresponden penelitian diperoleh bahwa yang menjadi faktor penghambat dalam pelaksanaan kepemimpinan virtual tersebut adalah keadaan geografis, membangun kepercayaan.

\section{Pembahasan}

Setiap pemimpin mempunyai gaya dan cara tersendiri dalam melakukan tindakan kepemimpinan terhadap pengikutnya. Hal ini sejalan dengan apa yang diungkapkan Sagala ${ }^{32}$ bahwa kepemimpinan merupakan seni dan ilmu dalam mempengaruhi seseorang atau kelompok.

\footnotetext{
32 Sagala, "Manajemen Dan Kepemimpinan Pendidikan Pondok Pesantren."
} 
Kepemimpinan kepala sekolah dapat dilihat dalam berbagai aspek yaitu kompetensi manajerial, kompetensi supervisi, kompetensi kepribadian, kompetensi kewirausahaan serta kompetensi sosial. Tentunya dalam setiap kompetensi tersebut mempunyai beberapa indikator yang dapat dilihat dan memberikan penilaian terhadap efektivitas kepemimpinan yang dilaksanakan oleh kepala sekolah.

Dalam hasil penelitian di atas menunjukkan bahwa efektifitas kepemimpinan virtual kepala sekolah dalam meningkatkan motivasi kinerja guru tergolong dalam kategori efektif. Hal ini dilihat dari perolehan nilai mean $82,7 \%$ yang berada dalam interval $67-83 \%$. Kendatipun kepemimpinan virtual kepala sekolah berada dalam kategori efektif akan tetapi dari beberapa aspek yang dijadikan acuan dalam melihat efektivitas tersebut beberapa indikator yang menunjukkan belum optimalnya dalam pelaksanaan kepemimpinan virtual tersebut.

Berdasarkan sebaran angket yang diberikan kepada koresponden penelitian diperoleh indikator yang menyebabkan kurang optimalnya kepemimpinan virtual tersebut terdapat dalam kompetensi manajerial kepala sekolah dalam pengelolaan sarpras sekolah serta pengelolaan tatausaha. Selain itu juga dalam kompetensi supervisi kurang optimalnya kepemimpinan virtual kepala sekolah dapat dilihat dalam memberikan stimulasi atau rangsangan usaha kreatif, penilaian dan pemberian fasilitas serta pemberian pengetahuan dan keterampilan.

Efektivitas kepemimpinan virtual kepala sekolah tersebut dipengaruhi oleh faktor pendukung dan penghambat dalam melaksanakan kepemimpinan virtual tersebut. Faktor pendukung dalam kepemimpinan virtual yaitu communication skill dan sosial networking skill. Berdasarkan hasil wawancara yang dilakukan dengan beberapa korensponden, kemampuan komunikasi kepala sekolah dalam melaksanakan kepemimpinan virtual sangat baik hal ini sangatlah penting karena kepemimpinan virtual tidak seperti kepemimpinan tradisional meskipun antara keduanya terjadi interaksi face to face, namun dalam kepemimpinan virtual kepala sekolah komunikasinya sangat terbatas dengan timnya. Dengan keahlian berkomunikasi yang baik yang dimiliki oleh kepala sekolah tentunya akan memaksimalkan dan mengoptimalkan pelaksanaan kepemimpinan yang dilakukannya. Keterampilan jejaring sosial merupakan salah satu faktor dalam pendukung dan penunjang dalam kepemimpinan virtual kepala sekolah. Kemampuan jejaring sosial kepala sekolah sangat dibutuhkan dalam implementasi kepemimpinan virtual, mengingat dalam pelaksanaannya dibantu oleh media internet, jaringan sosial seperti facebook, telegram, whatsapp, room, google meet dalam memimpin pengikutnya. Hal ini sesuai dengan pandangan Ningky Sasanti 
Munir ${ }^{33}$ situs sosial layaknya twitter, instagram, LINE dan semacamnya bisa digunakan oleh pemimpin dalam memimpin pengikutnya sehingga dibutuhkan keterampilan dalam penggunaannya dengan efektif untuk mencapai tujuan pendidikan. Berdasarkan hasil wawancara dengan koresponden, kemampuan jejering sosial kepala sekolah sangat memumpuni hal ini dikarenakan dalam melakukan komunikasi dengan masyarakat sekolah kepala sekolah cendrung menggunakan whatsapp, telegram dan facebook.

Lebih lanjut terkait faktor penghambat dalam implementasi kepemimpinan virtual dalam meningkatkan motivasi kinerja guru yaitu keadaan geografis dan membangun kepercayaan. Berdasarkan hasil wawancara terhadap beberapa koresponden menyatakan bahwa tidak semua guru berasal dari daerah sekitar sekolah. Sebagian berasal dari daerah yang keadaan geografisnya berbeda satu sama lainnya. Keadaan geografis memberikan dampak dalam optimalisasi kepemimpinan virtual kepala sekolah. Keadaan geografis yang baik dalam hal jangkauan jaringan internet akan memberikan pengaruh dalam pelaksanaan kepemimpinan virtual kepala sekolah akan terlaksana dengan optimal. Begitu juga jika keadaaan geografis kurang bagus dalam jangkauan jaringan internet akan memberikan pengaruh terhadap pelaksanaan kepemimpinan virtual kepala sekolah kurang optimal. Selain itu membangun kepercayaan antar semua anggota itu penting mengingat kepemimpinan virtual kepala sekolah dilaksanakan menggunakan media TIK yang menyebabkan intensitas interaksi antar anggota berkurang. Dengan kata lain keadaan geografis dengan membangun kepercayaan mempunyai hubungan yang erat. Letak geografis yang berjauhan tentunya akan mengurangi semangat komunikasi dan hubungan sosial antar kepala sekolah dan guru, padahal hubungan sosial dapat menimbulkan sikap saling memahami yang sangat diperlukan dalam membangaun kepercayaan antar anggota sekolah ${ }^{34}$.

\section{KESIMPULAN}

Kepemimpinan virtual yang dilakukan oleh kepala efektif dalam meningkatkan motivasi kinerja guru. Hal ini ditunjukkan dengan nilai rata-rata yang berada dalam kategori efektif dari indikator yang digunakan dalam penelitian tersebut. Sekalipun kepemimpinan virtual kepala sekolah berada dalam kategori efektif, akan tetapi masih terdapat beberapa komponen yang menyebabkan kurang optimalnya

\footnotetext{
${ }^{33}$ Munir, "Kepemimpinan Di Era Digital (E-Leadership)."

${ }^{34}$ Marketeers, "Virtual Leadership: Gaya Baru Kepemimpinan Efektif."
} 
kepemimpinan virtual tersebut. Selain itu adanya faktor pendukung dan penghambat yang mempengaruhi efektivitas kepemimpinan virtual kepala sekolah terhadap peningkatan motivasi kinerja guru. Oleh karenanya dibutuhkan dorongan (support) dari semua masyarakat sekolah terutama ketua yayasan yang mempunyai kewenangan dan pengambilan keputusan dengan memberikan dan menyediakan semua kebutuhan yang diperlukan dalam implementasi kepemimpinan virtual yang dilakukan oleh kepala sekolah. Bagi peneliti selanjutnya dapat mengkaji lebih dalam lagi kepemimpinan virtual dengan kajian yang berbeda sehingga bisa dijadikan acuan dan pijakan dalam memberikan solusi terhadap persolaan yang dihadapi. 


\section{DAFTAR PUSTAKA}

Diana, Eka, and Moh Rofiki. "Analisis Metode Pembelajaran Efektif Di Era New Normal." Jurnal Review Pendidikan Dan Pengajaran 3 (2020): 336-42.

Enas. "Efektivitas Kepemimpinan Kepala Sekolah Dalam Meningkatkan Kinerja Guru." Journal of Management Review 2, no. 3 (2018): 25260.

https://jurnal.unigal.ac.id/index.php/managementreview/article /view/1808/1486.

Hermawan, Iwan, Sri Eka Sadriatwati, and Nur Indah. "Virtual Leadership, Energizing Team Learning, Affective Commitment,." Prosiding Seminar Hasil Penelitian Dan Pengabdian Masyarakat Polines 3 (2020): 307-25.

Jamali, Arif, and Lantip Diat Prasojo. "Pengaruh Kompetensi Manajerial Kepala Sekolah, Lingkungan, Motivasi Guru Terhadap Prestasi Siswa SMA Muhammadiyah Kota Yogyakarta." Jurnal Akuntabilitas Manajemen 1, no. 1 (2013): 8-21.

Labaso', Syahrial. "KONSEP DASAR KEPEMIMPINAN DALAM PENDIDIKAN ISLAM." Jurnal Al-Ghazali 1, no. 2 (2018): 82102.

Leman, M.Mas'ud. "Pengaruh Gaya Kepemimpinan Virtual Terhadap Penguasaan Manajemen Dan Kinerja Kepala SD Di Tanah Grogot Kalimantan Timur." Jurnal Cendikia 14, no. 2 (2020): 196-211. https://doi.org/10.30957/Cendekia.v14i2.642.Sebagai.

Lisnawati, Rita. "Fungsi Manajemen Kepala Sekolah, Motivasi, Dan Kinerja Guru." Jurnal Pendidikan (Teori Dan Praktik) 2, no. 2 (2018): 143. https://doi.org/10.26740/jp.v2n2.p143-149.

Marketeers. "Virtual Leadership: Gaya Baru Kepemimpinan Efektif," 2012. https://www.marketeers.com/virtual-leadership-gayabaru-kepemimpinan-efektif/.

Menteri Pendidikan Nasional RI. "Permendiknas RI Nomor 13 Tahun 2007 Tentang Standar Kepala Sekolah/Madrasah.” Indonesia, 2007.

Munir, Ningky Sasanti. "Kepemimpinan Di Era Digital (E-Leadership)," 2020. https://swa.co.id/swa/my-article/kepemimpinan-di-eradigital-e-leadership.

Nasution, Wahyudin Nur. "Kepemimpinan Pendidikan Di Sekolah." Jurnal Tarbiyah 22, no. 1 (2015): 66-86.

Purnamasari, Sulfi. "Efektivitas Kepemimpinan Kepala Sekolah Dalam Meningkatkan Kinerja Guru SMA Yaspen Tugu Ibu Depok." Eduka: Jrnal Pendidikan, Hukum Dan Bisnis 6, no. 1 (2021): 1-14. 
Rofiki, Moh. "Urgensi Supervisi Akademik Dalam Pengembangan Profesionalisme Guru Di Era Industri 4.0." Indonesian Journal Pf Basic Education 2, no. 3 (2019): 502-14.

Rofiki, Moh, and Wardatul Munawaroh. Pengantar Manajemen Pendidikan Islam Teori Dan Praktik Di Sekolah. Malang: CV Ampuh Multi Rejeki, 2021.

Sagala, Syaiful. "Manajemen Dan Kepemimpinan Pendidikan Pondok Pesantren." Jurnal Tarbiyah 22, no. 2 (2015): 205-25.

Simarmata, Risda Herawati. "Upaya Peningkatan Motivasi Kerja Guru Sekolah Dasar." Jumal Administrasi Pendidikan 4, no. 1 (2016): 654 $-831$.

Yesmira Syamra. "Pengaruh Kompensasi Finansial Dan Motivasi Kerja Guru Terhadap Kinerja Guru Smk Negeri Pariwisata Di Kota Padang." Economica 4, no. 2 (2016): 266-76. https://doi.org/10.22202/economica.v4i2.628.

Tasrim, and Elihami. "MAHAGURU : Jurnal Pendidikan Guru Sekolah Dasar MOTIVASI KERJA PENDIDIK DALAM MENINGKATKAN MANAJEMEN LEMBAGA PENDIDIKAN DASAR," 2019, 42-47.

Wijaya, Dedy Kusumah. "Pentingnya Komunikasi Organisasi, Motivasi Kerja Dan Kompensasi Untuk Meningkatkan Kinerja Guru." Jurnal MIX VI, no. 2 (2015): 275-90.

Zamroni, Moh Rofiki, Fathor Rozi, Chusnul Muali, Imron Hamzah K, Taufiqul Majid, Dahlan Abdullah, et al. "E-Leadership in Education in Improving Teacher Competence in Industrial Revolution 4 . 0." Turkish Online Journal of Qualitative Inquiry (TOJQI) 12, no. 4 (2021): 1650-54.

Zulkifli, Mohammad, Arif Darmawan, and Edy Sutrisno. "Motivasi Kerja, Sertifikasi, Kesejahteraan Dan Kinerja Guru." Persona:Jumal Psikologi Indonesia 3, no. 2 (2014): 148-55. https://doi.org/10.30996/persona.v3i02.379. 